\title{
ELECTRICALLY CONDUCTIVE CERAMIC COMPOSITES
}

\author{
GIANPIETRO VAN DE GOOR, PETER SÄGESSER, \\ KARL BERROTH \\ EMPA \\ Swiss Federal Laboratories for Materials Testing and Research \\ Section 123, High Performance Ceramics \\ CH-8600 Duebendorf, Switzerland
}

\section{Abstract}

Basic results on the development of an electrically conductive, wear and corrosion resistant ceramic composite material are presented. From a closer examination of the composition dependence of the electrical conductivity in the binary system $\mathrm{ZrB}_{2}-\mathrm{B}_{4} \mathrm{C}$ we determined the percolation threshold at which an interconnected network of electrically conductive phase arises: for the system investigated, at a critical volume fraction of about 10 up to $25 \mathrm{Vol} .-\% \mathrm{ZrB}_{2}$ the electrical conductivity increased rapidly and above $40 \mathrm{Vol} .-\% \mathrm{ZrB}_{2}$ an electrical conductivity similar to metals was observed $\left(\sigma_{e}=10^{5}-10^{7} \mathrm{~S}^{\cdot} \mathrm{m}^{-1}\right)$.

Based on $\mathrm{ZrB}_{2}$ as major component and mainly $\mathrm{B}_{4} \mathrm{C}$ as minor component a ceramic composite material was obtained by net shape processing procedures. It exhibits a metal-like electrical conductivity, a high resistance against wear and oxidation as well as promising mechanical properties.

Keywords: percolation threshold, net shape, hot-isostatic pressing, mechanical properties. 


\section{Introduction}

Ceramic materials exhibit striking properties for high performance applications where high temperature stability, wear resistance and chemical inertness are demanded $[1,2]$. Up to now, several toughening techniques [3-6] were developed to overcome the problem of inherent brittleness of ceramics allowing ceramic parts to become more and more used in engineering, chemical processing and medical applications [3, 4, 7-9].

Wear and corrosion resistant, electrically conductive ceramics (ECCs) are interesting materials for applications where electrically conductive components or small precision parts with complex geometries are applied, e.g., electrodes, sensors, or precision parts in micromechanic and electronic devices. The development of ECCs with an electrical conductivity in the range of metals and with mechanical properties matching the requirements for technical applications is not straightforward: inherent ECCs [10] like transition metal carbides and borides are too brittle or poorly sinterable, and typical engineering ceramics are insulators. A promising approach to ECCs is to combine insulating engineering ceramics, e.g., $\mathrm{SiC}, \mathrm{B}_{4} \mathrm{C}, \mathrm{Al}_{2} \mathrm{O}_{3}, \mathrm{ZrO}_{2}, \mathrm{Si}_{3} \mathrm{~N}_{4}$ with an electrically conductive phase, e.g., $\mathrm{TiB}_{2}, \mathrm{ZrB}_{2}, \mathrm{TiC}, \mathrm{Mo}_{2} \mathrm{C}, \mathrm{Mo}, \mathrm{W}, \mathrm{MoSi}_{2}$ yielding ceramic/ceramic matrix or metal/ceramic matrix composites [11 - 15].

The goal of this work was to evaluate processing procedures which allow a net-shape fabrication of small but complex shaped components. Narrow tolerances, a very smooth surface finish, high wear resistance, and desired electronic conductivity should be reached without final machining.

\section{Experimental}

As a very promising system investigations were made with $\mathrm{ZrB}_{2}$ and $\mathrm{B}_{4} \mathrm{C}$ as major components.

Raw materials: $\mathrm{ZrB}_{2}\left(\mathrm{~d}=6.09 \mathrm{~g} \mathrm{~cm}^{-3}\right.$, grade B, H.C. Starck, Germany), $\mathrm{B}_{4} \mathrm{C}(\mathrm{d}=$ $2.51 \mathrm{~g} \cdot \mathrm{cm}^{-3}$, grade HS, H.C. Starck, Germany), detailed information on the powder characteristics are listed in table 1.

TABLE 1: Characteristic data on the $\mathrm{ZrB}_{2}$ and $\mathrm{B}_{4} \mathrm{C}$ raw materials

\begin{tabular}{ccccccccccc}
\hline & density & \multicolumn{3}{c}{ particle size distribution } & \multicolumn{2}{c}{ specific surface area, } & \multicolumn{3}{c}{ oxygen content } \\
& $\left(\mathrm{g} \mathrm{cm}^{3}\right)$ & $\mathrm{d}_{10}$ & $\mathrm{~d}_{50}$ & $\mathrm{~d}_{90}(\mu \mathrm{m})$ & $\mathrm{m}^{2} / \mathrm{g}$ & $\mathrm{m}^{2} / \mathrm{cm}^{3}$ & $w \mathrm{wt}-\%$ & $\mathrm{~g} / \mathrm{cm}^{3}$ & $\mathrm{~g} / \mathrm{m}^{2}$ \\
\hline $\mathrm{ZrB}_{2}$ & 6.09 & 0.86 & 2.7 & 5.2 & $2.04(2)$ & $12.4(1)$ & $0.99(5)$ & $6.0(3)$ & 0.48 \\
$\mathrm{~B}_{4} \mathrm{C}$ & 2.51 & 0.36 & 1.4 & 5.9 & $17.0(1)$ & $42.6(2)$ & - & & - \\
\hline
\end{tabular}


Powder blend preparation: The $\mathrm{ZrB}_{2}-\mathrm{B}_{4} \mathrm{C}$ compositions were prepared by vigorous dry-mixing the as-purchased powders in a melamine mortar for 10 minutes. For the synthesis of the $\mathrm{ZrB}_{2}$ composite materials an aqueous slurry of $\mathrm{ZrB}_{2}, \mathrm{~B}_{4} \mathrm{C}$ and sinterpromoting additives was prepared. Using a pearl mill (PML-H/V, Drais, Germany) with polyurethane lining and WC-Co milling bodies (6 wt.- $\%$ Co, $\varnothing 1 \mathrm{~mm}$ ) the average particle size was reduced from about $3 \mu \mathrm{m}$ to far below $1 \mu \mathrm{m}\left(\mathrm{d}_{50} \approx 0.5 \mu \mathrm{m}\right)$. Then, organics were added to the slurry, i.e., surfactants to adjust the viscosity of the slurry for spray drying, pressing aids to improve the particle re-arrangement during powder compaction and polyvinylalcohol as binder to increase the strength of the resulting green bodies [16]. By spray drying (spray dryer Mobile Minor, type "Hi-Tec", Niro, Denmark) a granulated powder consisting of spherical granules up to $200 \mu \mathrm{m}$ in diameter with excellent flowability and good compaction behaviour was obtained.

These granulated powder blends were compacted by uniaxial die pressing (30 MPa) to cylindrical pellets $(\varnothing 15 \mathrm{~mm}$, thickness $8 \mathrm{~mm}$ ) which were additionally cold-isostatic pressed (150 MPa) in a wet-matrix press (type 110-350-200, VITEK N.V., Belgium). Densities of the green bodies were determined from geometric dimensions and weight of the samples.

The sintering was performed in a graphite furnace equipped with a dilatometer device for rate-control sintering (KCE Rödental, Germany). Initial sintering was done in vacuum up to $1800 \mathrm{~K}$ and final sintering in $\mathrm{Ar}$ atmosphere $\left(1 \mathrm{bar},>1800^{\circ} \mathrm{K}\right)$.

For hot-isostatic pressing a laboratory HIP (EPSInt, Belgium) with graphite heater, shielding and crucibles, (Ar, HIP gas) was used.

Characterisation of sintered material was done by following equipment and procedures:

Optical microscopy: ZEISS Axiovert 100 A, magnification 100x.

Scanning electron microscope (SEM): JEOL JSM-6300F, $20 \mathrm{kV}$, BSE mode, magnification $1000 \times$.

$X$-ray diffractometry: Siemens diffractometer, $\Theta / 2 \Theta$ scan, continuous mode: $0.1^{\circ} \Theta \cdot \mathrm{s}^{-1}$.

Thermogravimetric analysis: Perkin Elmer TGA 7, alumina crucibles, sample weight: 20-30 $\mathrm{mg}$, heating rate: $10 \mathrm{~K} \cdot \mathrm{min}^{-1}$, atmosphere: oxygen.

Particle size distribution: Laser diffraction (MasterSizer X, Malvern Instruments) isopropanol as dispersing liquid.

Specific surface area (BET): BET measurement according to DIN 66'131, nitrogen adsorption, sorption apparatus (PMI).

Oxygen content: combustion of carbon using ultrapure $\mathrm{Ni}$ as catalyst at about $3300 \mathrm{~K}$ in an induction furnace, quantitative determination of generated $\mathrm{CO}_{2}$ by infrared detection (LECO TC-336), mean value from 5 measurements, sample weight: $10-20 \mathrm{mg}$.

Density (d): ARCHIMEDES principle, water/air. 
Electrical conductivity $(\sigma e)$ : 4-point van der Pauw method, $10 \times 5 \times 2 \mathrm{~mm}$ sample plates, current: $0.500 \pm 20 \mathrm{~A}\left(\sigma \mathrm{e}>10^{4} \mathrm{~s} \cdot \mathrm{m}^{-1}\right), 0.15 \pm 20 \mathrm{~A}\left(\sigma \mathrm{e}>10^{4} \mathrm{~s} \cdot \mathrm{m}^{-1}\right)$.

Vickers hardness (HV10): according to standard proposal ENV 843-4, $10 \mathrm{kN}$ load, microhardness tester Durimet KLHP.

Bending strength $\left(\sigma_{b}\right): 2.0 \times 2.5 \times 25.0 \mathrm{~mm}$ test bars and 4-point bending strength measurements according to standard EN 843-1, test time: $10 \pm 1 \mathrm{~s}, 20 / 10 \mathrm{~mm}$ distance of power transmitter, screw driven compression test apparatus Zwick; calculation of mean bending strength values from five measurements according to standard proposal ENV 843-5.

Fracture toughness (KIC): SEVNB method, $2.0 \times 2.5 \times 25.0 \mathrm{~mm}$ test bars according to standard EN 843-1, V-notch: radius $=0.01-0.03 \mathrm{~mm}$, depth $=0.5-0.8 \mathrm{~mm}$, $20 / 10 \mathrm{~mm}$ distance of power transmitter, load speed: $\approx 0.25 \mathrm{MPa} \cdot \sqrt{\mathrm{m}} \cdot \mathrm{s}^{-1}$, screw driven compression test apparatus (Zwick), calculation of $\mathrm{K}_{\mathrm{IC}}$ values according to DIN 51' 109.

Young's modulus (E): impulse-echo technique, ultrasonic apparatus (USIP 12 Krautkrämer) using honey as coupling agent, longitudinal wave generator head (Harisonic HLI CM1002), transversal wave generator head (Krautkrämer MB4Y, 10 $\mathrm{MHz} \mathrm{NB} / 5 \mathrm{MHz} \mathrm{BB})$.

\section{Results and Discussion}

$\mathrm{ZrB}_{2}-\mathrm{B}_{4} C$ composites: For densification of the powder compacts a simple pressureless sintering procedure with continuous heating rate up to the maximal sintering temperature $(2450 \mathrm{~K}$, hold time: $20 \mathrm{~min}$.) was applied. Composites containing 40 to 80 Vol.- $\% \mathrm{ZrB}_{2}$ yield the highest densification with densities greater than $93 \%$ relative to the theoretical density value (Figure 1). 


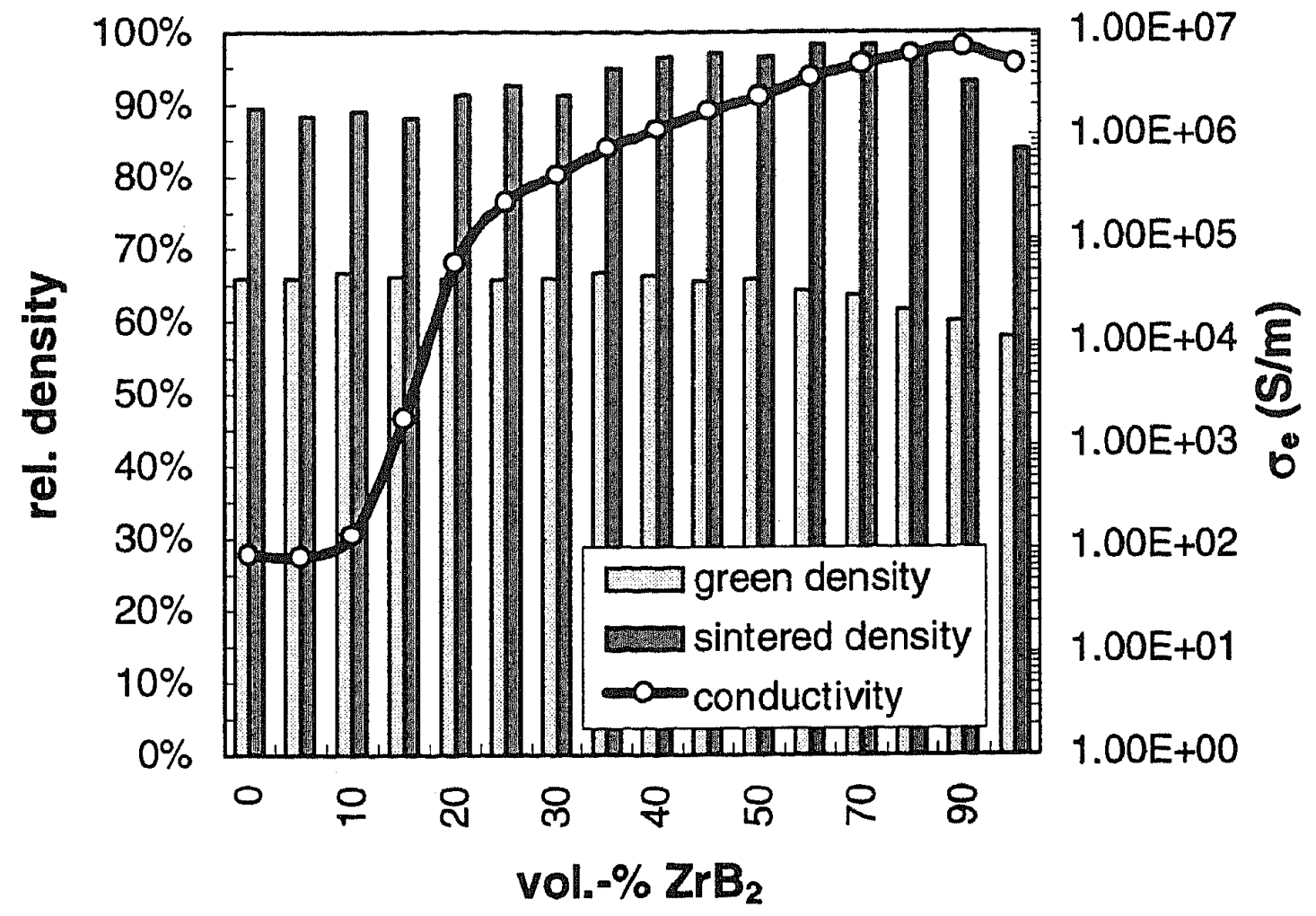

Figure 1: Electrical conductivity, green density and sintered density vs. composition of $\mathrm{ZrB}_{2}-\mathrm{B}_{4} \mathrm{C}$ composite materials

The pure ceramic powder compacts of $\mathrm{B}_{4} \mathrm{C}$ and $\mathrm{ZrB}_{2}$ resp., instead showed only poor sinterability with $90 \%$ resp. $85 \%$ relative density. Therefore, expensive hot-pressing was usually applied to the manufacturing of dense ceramic parts of both, pure $\mathrm{B}_{4} \mathrm{C}$ and $\mathrm{ZrB}_{2}$. $[4,5]$. For $\mathrm{B}_{4} \mathrm{C}$ the inherent poor sintering properties have been traced back to the covalent character of its framework resulting in low self-diffusion coefficients and high grain boundary energies $[17,18]$. Most efforts to obtain dense boride materials concern $\mathrm{TiB}_{2}$ which possesses excellent resistance against metallic melts $[4,5]$. It was stated that the high oxygen loading of the $\mathrm{TiB}_{2}$ surface is the main reason for its poor sintering properties. This argument was confirmed by producing and handling $\mathrm{TiB}_{2}$ powders under inert atmosphere conditions which resulted in pressureless sintered ceramic parts with nearly theoretical density $[19,20]$. We suppose that for $\mathrm{ZrB}_{2}$ similar considerations are valid. From this point of view, the excellent densification of $\mathrm{ZrB}_{2}$ $\mathrm{B}_{4} \mathrm{C}$ powder compacts may be explained by reduction of the oxygen covered $\mathrm{ZrB}_{2}$ surface by $\mathrm{B}_{4} \mathrm{C}$ which forms volatile $\mathrm{B}_{2} \mathrm{O}_{3}$ and $\mathrm{CO}_{2}$. From the processing of $\mathrm{SiC}$ it is well known that small additions of carbon and $\mathrm{B}_{4} \mathrm{C}$ cause a significant increase in the sinter reactivity of $\mathrm{SiC}$ [21]. Beside the reduction of the oxide layer on the $\mathrm{SiC}$ particles by carbon, the formation of an eutectic liquid $\mathrm{SiB}_{6}$ phase by reaction of $\mathrm{SiC}$ with $\mathrm{B}_{4} \mathrm{C}$ occurs which promotes the sintering kinetics by dissolution/recrystallization processes (liquid phase sintering) $[4,18,22]$. From optical microscopy and $\mathrm{X}$-ray diffractometry within the actual investigation no indications of the formation of a comparable glassy phase or other crystalline phases than $\mathrm{B}_{4} \mathrm{C}$ and $\mathrm{ZrB}_{2}$ are observed (Figure 2). 


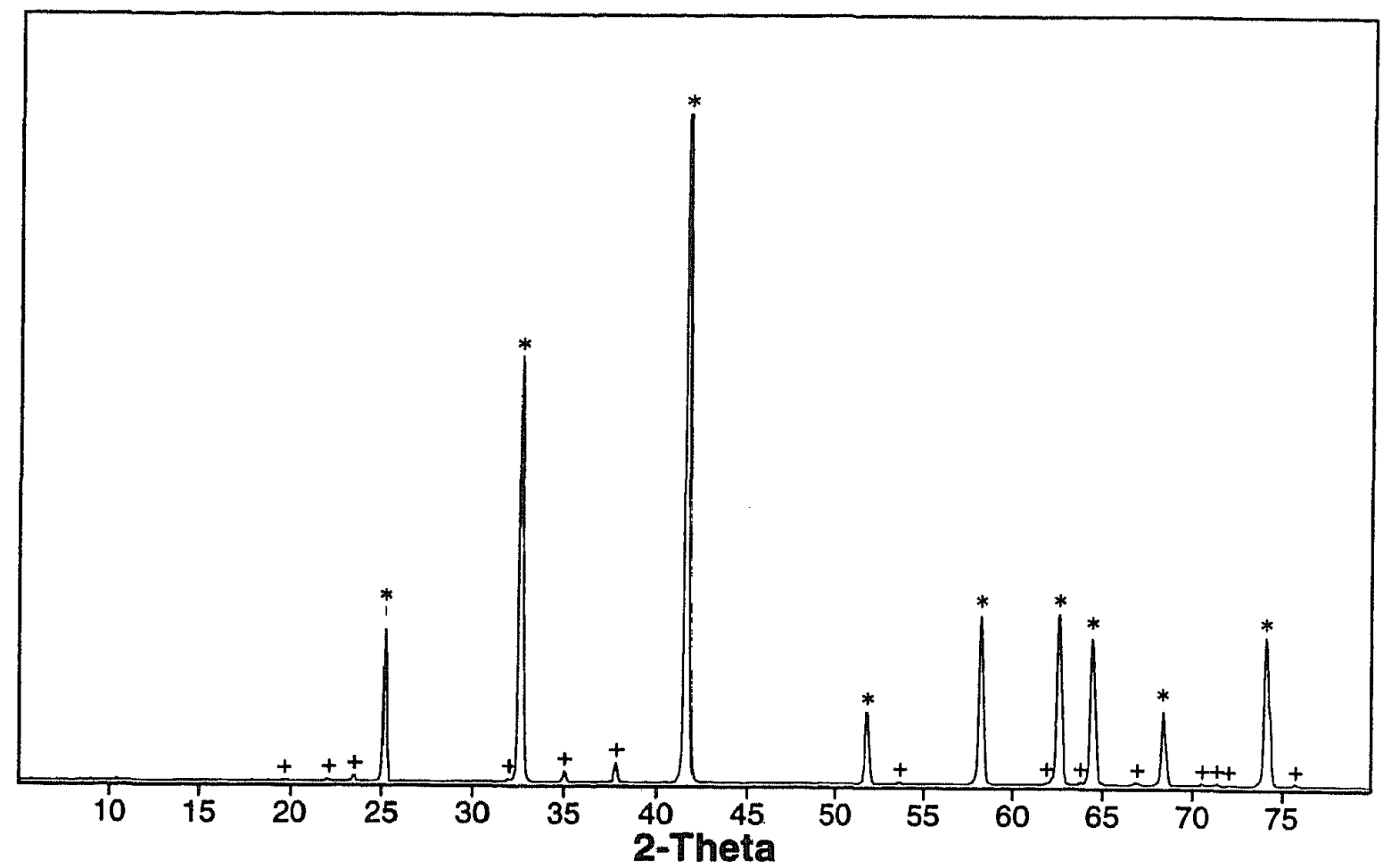

Figure 2: X-ray diffractogram of $\mathrm{ZrB}_{2}(*)-\mathrm{B}_{4} \mathrm{C}(+)$ composite material $\left(50 \mathrm{Vol} . \% \mathrm{ZrB}_{2}\right)$

A comparison of the lattice constants of the composite phases with literature values of standard materials (table 2) shows excellent coincidence for the $\mathrm{ZrB}_{2}$ phase and good agreement for $\mathrm{B}_{4} \mathrm{C}$ which is the carbon-rich limiting composition in the broad composition field [17]. Hence, we suppose that solid solution mechanisms enhancing the sintering relevant diffusion processes are neglectable.

TABLE 2: Refined lattice constants of reference materials in comparison to the corresponding phases in the sintered composite material:

\begin{tabular}{ccccccc}
\hline & \multicolumn{2}{c}{$\mathrm{ZrB}_{2}$} & \multicolumn{2}{c}{$\mathrm{B}_{4} \mathrm{C}$} \\
\hline $\begin{array}{l}\text { reference } \\
\text { material }^{\mathrm{a}}\end{array}$ & $\mathrm{a}=3.169 \AA$ & $\mathrm{c}=3.530 \AA$ & $\gamma=120^{\circ}$ & $\mathrm{a}=5.60 \AA$ & $\mathrm{c}=12.10 \AA$ & $\gamma=120^{\circ}$ \\
$\mathrm{ZrB}_{2}-\mathrm{B}_{4} \mathrm{C}$ & $\mathrm{a}=3.169 \AA$ & $\mathrm{c}=3.531 \AA$ & $\gamma=120^{\circ}$ & $\mathrm{a}=5.595 \AA$ & $\mathrm{c}=12.071 \AA$ & $\gamma=120^{\circ}$ \\
\hline
\end{tabular}

${ }^{a}$ ref. 4, p. 791 and 805 .

The electrical conduction behaviour is strongly dependent on the volume fraction of $\mathrm{ZrB}_{2}$ present in the composite system (Figure 1). It agrees with the statements of the percolation theory which means that in a binary system consisting of an insulating and an electrically conductive phase at a critical volume fraction $V_{C}$, the conductive phase forms a three-dimensional interconnected network of conduction paths allowing the electrons to percolate through the material (Figure 3) and so yielding a sharp increase in the specific conductivity [23]. 

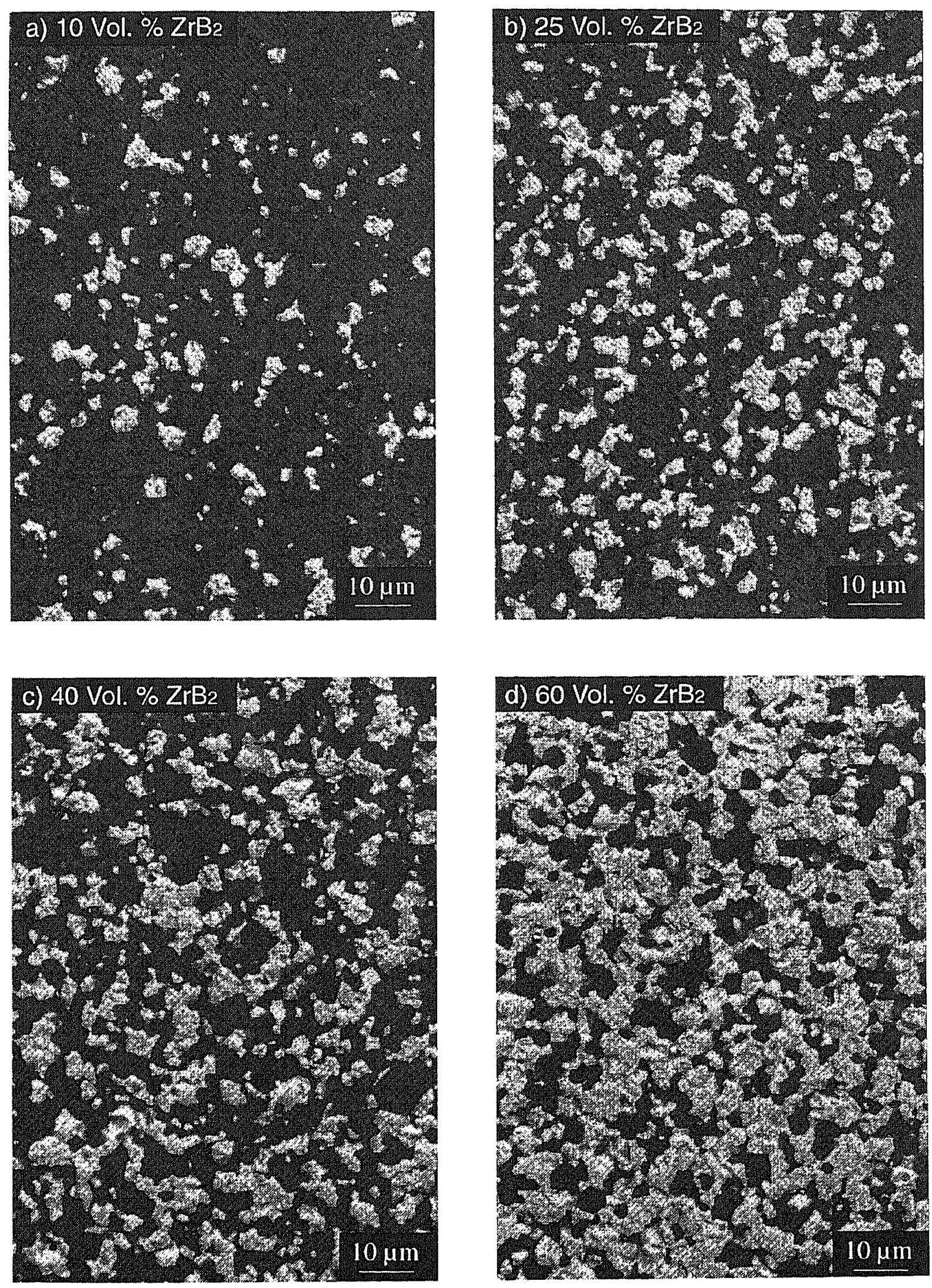

Figure 3: Microstructure vs. composition of $\mathrm{ZrB}_{2}-\mathrm{B}_{4} \mathrm{C}$ composite materials (SEM micrographs of fracture surfaces: white $-\mathrm{ZrB}_{2}$, grey $-\mathrm{B}_{4} \mathrm{C}$, dark grey - pores or materials pull out). 
Up to now, it was not possible to develop a theoretical model for binary ceramic composites for a predictive simulation of their electrical conductivity [23]. This fact results mainly from the complexity of such ceramic systems since factors influencing the critical volume fraction like particle size ratio, particle morphologies and particle interfaces are not only strongly dependent on the initial powders used, but also on the processing conditions especially on sintering which directly controls grain growth. For the investigated binary system the critical volume fraction $V_{c}$ is about $10 \mathrm{Vol} . \% \mathrm{ZrB}_{2}$, between 10 and 25 Vol.-\% the percolation threshold is reached and above $50 \mathrm{Vol} . \%$ $\mathrm{ZrB}_{2}$ a close network is present which results only in minor increase in electrical conductivity with rising $\mathrm{ZrB}_{2}$ content (Figure 1).

In Figure 4 the thermally induced weight loss of a $\mathrm{ZrB}_{2}-\mathrm{B}_{4} \mathrm{C}$ powder blend (50-50 Vol.-\%, ) in oxygen atmosphere is depicted. Up to about $700^{\circ} \mathrm{K}$ organic additives are burned out and at about $800^{\circ} \mathrm{K}$ the oxidative degradation of the ceramic components occurs.

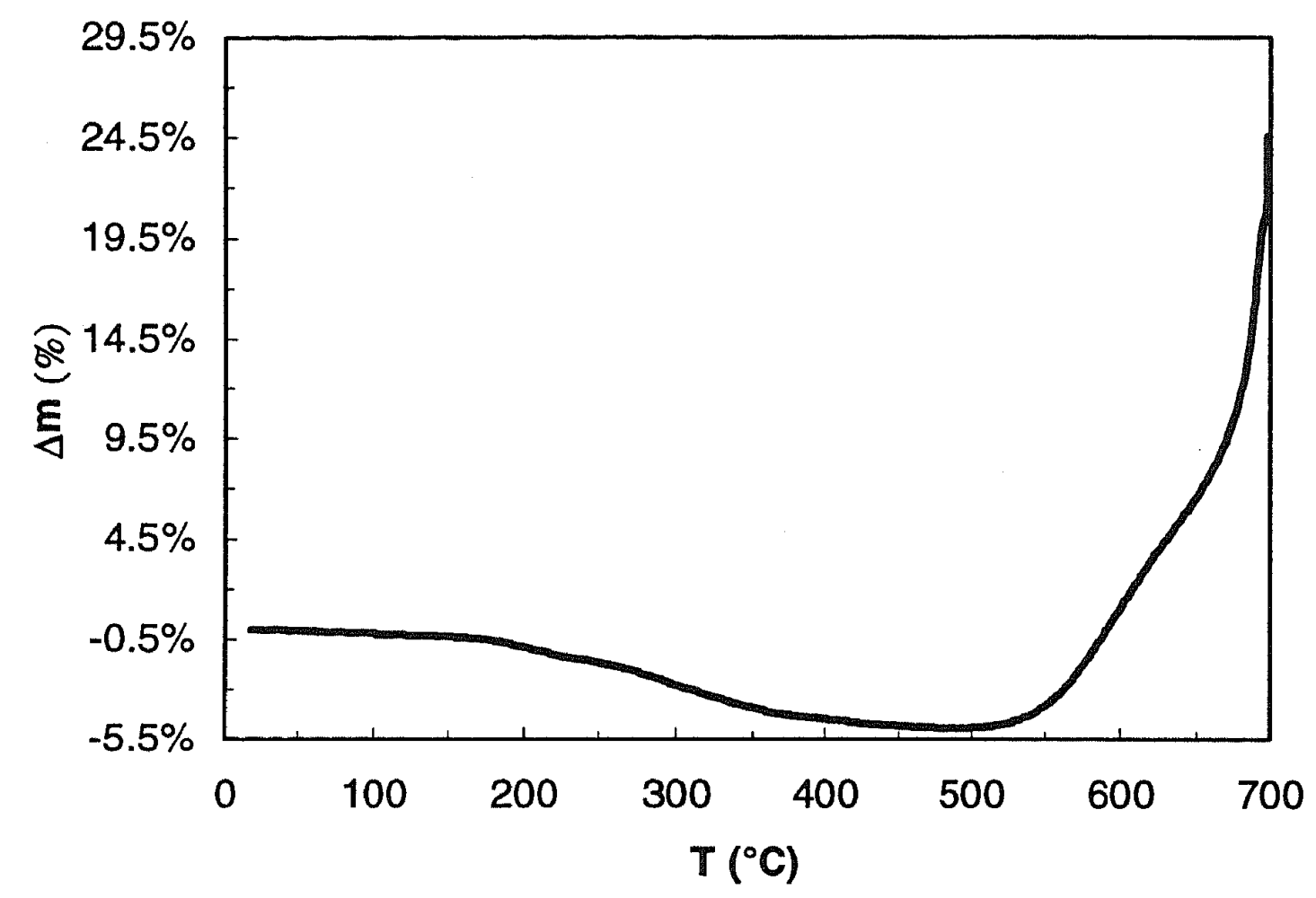

Figure 4: Thermogravimetric graph depicting the oxidative removal of organic additives and the oxidation resistance of $\mathrm{ZrB}_{2}-\mathrm{B}_{4} \mathrm{C}$ composite material (50 Vol.\% $\mathrm{ZrB}_{2}$ ).

$\mathrm{ZrB}_{2}$ composite material: The addition of sinter promoting additives to the $\mathrm{ZrB}_{2}-\mathrm{B}_{4} \mathrm{C}$ composite made it possible to obtain a composite material with almost theoretical density; at least higher than $95 \%$ of the relative density. Figure 5 shows micrographs of polished composite surfaces after different densification procedures which depict the importance of sintering conditions with respect to microstructural development and hence to mechanical properties (Table 3). 
Table 3: Properties of $\mathrm{ZrB}_{2}$ composite materials after different densification procedures.

\begin{tabular}{|c|c|c|c|c|c|c|}
\hline sintering conditions & $\begin{array}{l}\text { density d } \\
\left(\mathrm{g} / \mathrm{cm}^{3}\right)\end{array}$ & $\begin{array}{c}\text { Vickers hardness } \\
\text { HV10 }\end{array}$ & $\begin{array}{l}\text { 4-point bending } \\
\text { strength } \sigma_{b} \\
(\mathrm{MPa})\end{array}$ & $\begin{array}{l}\text { fracture toughness } \\
\qquad \mathrm{K}_{\mathrm{IC}} \\
(\mathrm{Mpa} \quad \sqrt{\mathrm{m}})\end{array}$ & $\begin{array}{l}\text { Young's modulus E } \\
(\mathrm{GPa})\end{array}$ & $\begin{array}{c}\text { electrical } \\
\text { conductivity } \sigma_{\mathrm{e}} \\
(\mathrm{S} / \mathrm{m})\end{array}$ \\
\hline $\begin{array}{l}\text { pressureless sintering } \\
\text { with linear heating: } \\
\mathrm{T}_{\max }=2450 \mathrm{~K}\end{array}$ & 4.17 & $1340(50)$ & $300(60)$ & $3.5(6)$ & & \\
\hline $\begin{array}{l}\text { pressureless rate- } \\
\text { control sintering (r.c.s.): } \\
\mathrm{T}_{\max }=2420 \mathrm{~K}\end{array}$ & 4.17 & $1700(80)$ & $460(60)$ & $3.4(6)$ & $381(4)$ & $8(2) \cdot 10^{5}$ \\
\hline $\begin{array}{l}\text { r.c.s. + hot-isostatic } \\
\text { pressing (HIP): } \\
\mathrm{T}_{\mathrm{HIP}}=2220 \mathrm{~K}, \\
\mathrm{P}_{\mathrm{HIP}}=195 \mathrm{MPa}\end{array}$ & 4.37 & $2090(90)$ & $480(60)$ & $3.5(1)$ & $498(5)$ & \\
\hline
\end{tabular}


a)

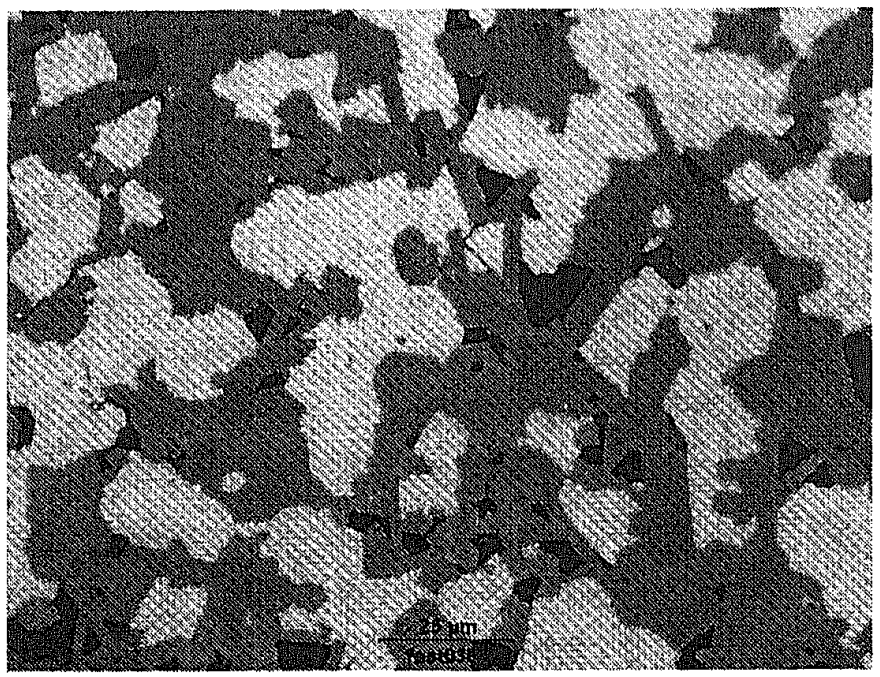

b)

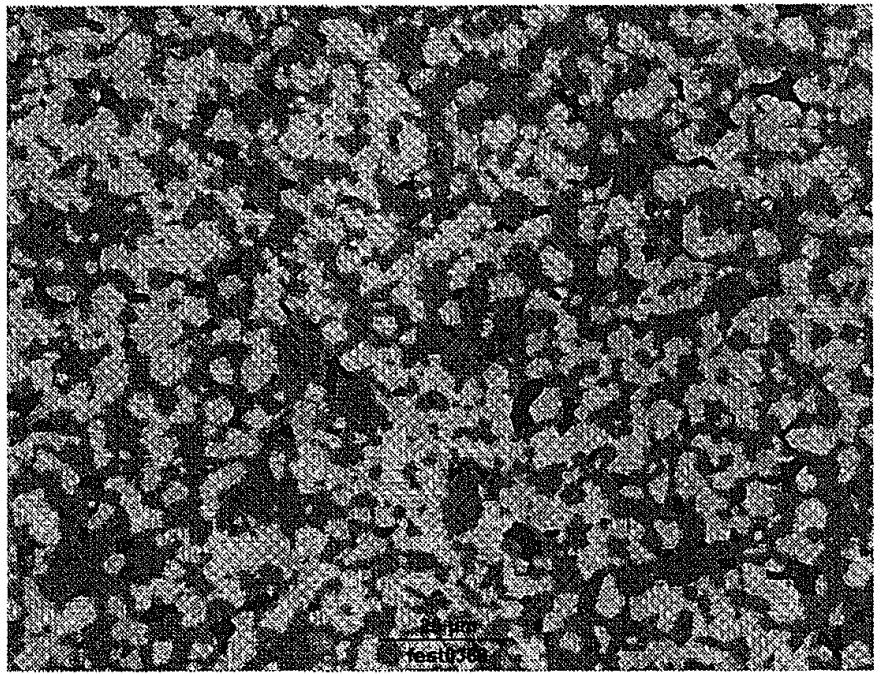

c)

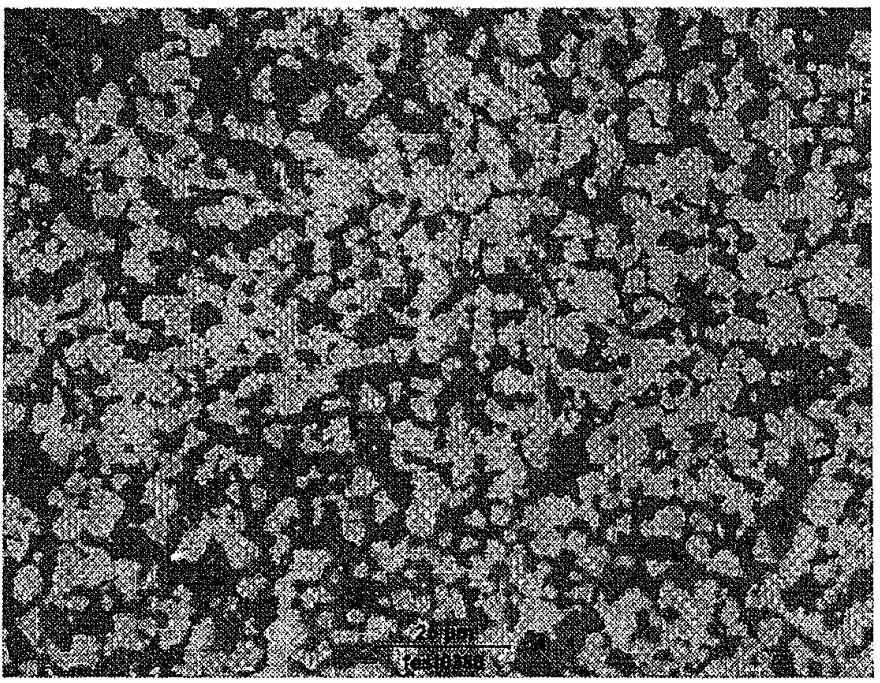

Figure 5: Microstructure of $\mathrm{ZrB}_{2}$ composite materials after different densification procedures: a) pressureless sintering with continuous heating rate, b) pressureless rate-control sintering, c) process b) with subsequent hotisostatic pressing (optical micrographs of polished surfaces: white $-\mathrm{ZrB}_{2}$, grey - mainly $\mathrm{B}_{4} \mathrm{C}$, black - pores or materials pull out). 
By adjusting the temperature program of pressureless sintering $\left(2450^{\circ} \mathrm{K}, 20 \mathrm{~min}\right.$.) and using rate-control a tremendous decrease in grain growth was achieved and by additional hot-isostatic pressing (195 MPa, $2200 \mathrm{~K}, 20 \mathrm{~min}$.) the grain contacts were improved which is evident from the significant decrease in porosity and of grain pull outs due to the polishing procedure and the large increase in hardness. Comparison of the achieved densities after pressureless sintering $\left(d=4.17 \mathrm{~g} \cdot \mathrm{cm}^{-3}=96.5 \% \mathrm{TD}\right)$ and sinter-HIPing $\left(\mathrm{d}=4.37 \mathrm{~g} \cdot \mathrm{cm}^{-3}, 101.2 \%\right.$ TD) with the theoretical value $\left(4.32 \mathrm{~g} \mathrm{~cm}^{-3}\right)$ shows a significant positive discrepancy for the sinter-HIP material indicating that $\mathrm{B}_{4} \mathrm{C}$ $\left(\mathrm{d}=2.51 \mathrm{~g} \cdot \mathrm{cm}^{-3}\right)$ indeed was consumed during sintering as already stated above.

\section{Conclusions}

With the present work we have elaborated net shape processing procedures for the fabrication of composite components with the following properties:

- Electrical Conductivity: In $\mathrm{ZrB}_{2}-\mathrm{B}_{4} \mathrm{C}$ composites the percolation threshold is observed at 10 to 25 vol.- $\% \mathrm{ZrB}_{2}$ giving rise to an increase in the electrical conductivity from about $10^{2}$ to $10^{6} \mathrm{~S}^{-1}$. Hence, more than about 25 vol.- $\% \mathrm{ZrB}_{2}$ are necessary to achieve an electrical conductivity similar to metals.

- Densification and Microstructure: Both pure $\mathrm{B}_{4} \mathrm{C}$ and pure $\mathrm{ZrB}_{2}$ powder compacts are harder to densify than their composites. Fine dispersed powder blends with average particle sizes in the micron to submicron range and optimized sintering conditions yield microstructures with grain sizes below $5 \mu \mathrm{m}$ allowing the desired surface finish for net shape fabrication.

- Phase Composition: X-ray diffractograms of $\mathrm{ZrB}_{2}-\mathrm{B}_{4} \mathrm{C}$ composites show only $\mathrm{ZrB}_{2}$ and $\mathrm{B}_{4} \mathrm{C}$ as crystalline phases. The refined lattice parameters agree with literature data. With SEM and optical micrographs no amorphous phases were observed. Therefore, no indication for liquid phase sintering is evident in this system.

- Oxidation Resistance: Thermogravimetric analysis on $\mathrm{ZrB}_{2}$ composite powder blends in oxygen atmosphere demonstrate the high resistance of the material against oxidation which begins only above $800^{\circ} \mathrm{K}$. Therefore, complete oxidative removal of organic additives (binder, pressing aid, surfactants) as crucial step in ceramic processing should be possible in air.

- Mechanical Properties: The mechanical properties are improved with higher densification, decreasing porosity and finer microstructure. Due to closer grain contacts the strength and hardness of the $\mathrm{ZrB}_{2}$ composite are enhanced remarkably.

\section{Acknowledgement}

We are grateful to the Commission for Technology and Innovation (CTI) in Switzerland for financial support under contract No. 2945.1. 


\section{References}

[1] Petzow, G., Aldinger, F. (1993) Spektrum der Wissenschaft, 102.

[2] Gauckler, L.J. (1989) Chimia 43, 290.

[3] Becher, P.F. (1991) J. Am. Ceram. Soc. 74, 255.

[4] Engineered Materials Handbook, Vol. 4: Ceramics \& Glasses, AST International 1991.

[5] Materials Science and Technology (Eds.: R.W. Cahn et al.), Vol. 13, VCH 1993

[6] Telle, R., Brook, R.J., Petzow, G., Hard, J. (1991) Mater. 2, 79.

[7] Berroth, K. (1994) Keram. Z. 46, 19.

[8] Rieger, W. (1989) Chimia 43, 309.

[9] Peppas, N.A., Langer, R. (1994) Science 263, 1715.

[10] Wang, C.C., et al. (1995) J. Mater. Sci. 30, 1627.

[11] Claussen, N., et al. (1994) cfi/ber. DKG 71, 301.

[12] Jimbou, R., et al. (1986) Adv. Ceram. Mater. 1, 341.

[13] Swamy, C.S., Weimar, P. (1970) Powder Metall. Int. 2, 134.

[14] Newkirk, M.S., et al. (1986) J. Mater. Res 1, 81.

[15] Hillig, W.B. (1994) Am. Ceram. Soc. Bull. 73, 56.

[16] Hoffmann, E.R. (1972) Bull. Am. Ceram. Soc. 51, 240.

[17] Thévenot, F. (1990) J. Europ. Ceram. Soc. 6, 205.

[18] Böcker, W., Hamminger, R. (1991) Interceram 40, 520.

[19] Finch, C.B. et al. (1986) Adv. Ceram. Mater. 1, 50.

[20] Baik, S., Becher, P.F. (1987) J. Am. Ceram. Soc. 70, 527.

[21] Mizrah, T., Hoffmann, M., Gauckler, L. (1984) Powder Metall. Int. 16, 217.

[22] Schwetz, K.A., Reinmuth, K. , Lipp, A. (1983) Sprechsaal 116, 1063.

[23] Lux, F. J. (1993) Mater. Sci. 28, 285, and references quoted. 